\title{
Mitochondrial Dynamics of Bcl-2 Family During E2- Induced Apoptosis Correlates with the Malignant of Endometrial Cancer Cells
}

\section{Takahiro Yaguchi ( $\nabla$ yaguchi@iuhw.ac.jp )}

International University of Health and Welfare Department of Healthcare: Kokusai Iryo Fukushi Daigaku

Fukuoka Hoken Gakubu https://orcid.org/0000-0002-4660-5123

Hirofumi Taira

International University of Health and Welfare: Kokusai Iryo Fukushi Daigaku

Misaki Kameno

Konan University: Konan Daigaku

Junji Kawakami

Konan University: Konan Daigaku

\section{Research Article}

Keywords: E2, mitochondrial membrane potential, Bcl-2 family, caspase, apoptosis

Posted Date: January 31st, 2022

DOI: https://doi.org/10.21203/rs.3.rs-1260502/v1

License: (c) (i) This work is licensed under a Creative Commons Attribution 4.0 International License.

Read Full License 
Mitochondrial dynamics of Bcl-2 family during $E_{2}$-induced apoptosis correlates with the malignant of endometrial cancer cells

Takahiro Yaguchi ${ }^{1}$, Hirofumi Taira ${ }^{1}$, Misaki Kameno ${ }^{2}$, Junji Kawakami ${ }^{2}$

Running title: $\mathrm{E}_{2}$ disturbs mitochondrial membrane potentials via a different mechanism in HEC1 and HEC50B cells

1 Department of Medical Laboratory Science, Graduate School of Health and Welfare Sciences, International University of Health and Welfare, 137-1 Enokizu, Okawa, Fukuoka 831-8501, Japan

2 Department of Nanobiochemistry, Frontiers of Innovative Research in Science and Technology (FIRST), Konan University, 7-1-20 Minatojima-Minamimachi, Chuo-ku, Kobe, 650-0047, Japan

Corresponding to Takahiro Yaguchi. Department of Medical Laboratory Science, Graduate School of Health and Welfare Sciences, International University of Health and Welfare, 137-1 Enokizu, Okawa, Fukuoka, 831-8501, Japan

Tel.: +81-944-89-2000; Fax. +81-944-89-2000

E-mail address: yaguchi@iuhw.ac.jp 


\begin{abstract}
Endometrial adenocarcinoma has two type: Type I has an estrogen-derived etiology and low-grade endometrial cancer cells, on the other hand, Type II occurs estrogenindependent and is high-grade endometrial cancer cells. However, it is not well understood that the relationship between the exposure of estrogen and the grade of endometrial cancer cells. So, we investigated how estrogen affected the grade of endometrial cancer cells. In the present study, we focused on the localization and expression of Bcl-2 family that regulate the mitochondrial membrane potential in HEC1 and HEC50B cells. Cell viability was decreased by $17-\beta$-estradiol $\left(\mathrm{E}_{2}\right)$ and $\mathrm{E}_{2}$ disturbed the mitochondrial membrane potential followed by activating caspase- 9 and caspase- 3 in both cells. These results suggested that $\mathrm{E}_{2}$ induced apoptosis in HEC1 and HEC50B cells. B-cell lymphoma 2 (Bcl-2) and Bcl-2-associated death promoter (Bad) expression were decreased and B-cell lymphoma-extra large $\left(\mathrm{Bcl}-\mathrm{X}_{\mathrm{L}}\right)$ and Bcl-2-associated $\mathrm{X}$ protein (Bax) expression were increased at the mitochondrial outer membrane in HEC1 cells. On the other hand, Bcl-2 and Bcl- $\mathrm{X}_{\mathrm{L}}$ expression were decreased and Bad and Bax expression were increased at the mitochondrial outer membrane in HEC50B cells. In conclusion, the dynamics of the Bcl-2 family during $\mathrm{E}_{2}$-induced apoptosis was found to be different depending on the grade of endometrial cancer cells. We hope that the dynamics of Bcl-2 family proteins such as $\mathrm{Bcl}-\mathrm{X}_{\mathrm{L}}$ and Bad will be used to diagnose the grade of malignant of endometrial cancer cells.
\end{abstract}

Key words: $E_{2}$, mitochondrial membrane potential, Bcl-2 family, caspase, apoptosis

\title{
Introduction
}

The number of patients suffering from endometrial adenocarcinomas is increasing over the world, because the endometrial adenocarcinomas are difficult to discover more than cervical cancer. Endometrial adenocarcinomas have two types, such as Type I and Type II. It is well-known that Type I is dependent on the continuously exposure of estrogen, on the other hand, Type II is independent of estrogen [1-4]. In histological classify, it is divided into Grade I, Grade II and Grade III according to the percentage of 
undifferentiated [5-7]. Type II and Grade III endometrial adenocarcinomas are more aggressive endometrial cancer cells [8-10].

B-cell lymphoma 2 (Bcl-2) family proteins, such as Bcl-2, B-cell lymphoma-extra large $\left(\mathrm{Bcl}-\mathrm{X}_{\mathrm{L}}\right)$, Bcl-2-associated death promoter $(\mathrm{Bad})$ and $\mathrm{Bcl}-2$-associated $\mathrm{X}$ protein (Bax), play an important role in the maintenance of mitochondrial membrane potentials with changing the affinities, localization and local relative abundance of these proteins [11]. The affinities between the Bcl-2 family proteins are the result of protein conformation changes, most of which occur on the mitochondrial outer membrane. Bcl2 and $\mathrm{Bcl}-\mathrm{X}_{\mathrm{L}}$ belong to anti-apoptotic proteins and contain the Bcl-2 homolog $(\mathrm{BH}) 1$, $\mathrm{BH} 2, \mathrm{BH} 3$ and $\mathrm{BH} 4$ domains. Bad and Bax belong to pro-apoptotic proteins and Bad contain the $\mathrm{BH} 3$ domains, on the other hand, Bax contain the $\mathrm{BH} 1, \mathrm{BH} 2$ and $\mathrm{BH} 3$ domains [12-14]. Bcl-2, Bcl- $\mathrm{X}_{\mathrm{L}}$ and Bax have the transmembrane domain, but not Bad. The affinity between Bcl-2 and Bax is higher than that between Bcl-2 and Bad. Moreover, the affinity between $\mathrm{Bcl}-\mathrm{X}_{\mathrm{L}}$ and $\mathrm{Bad}$ is higher than that between $\mathrm{Bcl}-\mathrm{X}_{\mathrm{L}}$ and Bax. Thus, Bcl- $\mathrm{X}_{\mathrm{L}}$ recruits Bax on the mitochondrial outer membrane followed by Bax homo-oligomerization and pore formation within the mitochondrial outer membrane [1517]. The mitochondrial membrane potentials are disturbed by Bax pore formation followed by releasing cytochrome c (Cyt c) and/or second mitochondria-derived activator of caspase (SMAC)/DIABLO from mitochondria to cytosol. The activation of caspase9 by Cyt $\mathrm{c}$ and/or the neutralization of inhibitor of apoptosis (IAP) family of apoptosis of SMAC/DIABLO induce apoptosis [18-21].

The present study focused on the mitochondrial membrane potential and the dynamics of Bcl-2 family proteins in HEC1 and HEC50B cells. 17- $\beta$-estradiol $\left(\mathrm{E}_{2}\right)$ disturbed mitochondrial membrane potential depending on changing the localization of $\mathrm{Bcl}-2$ family. Especialy, there was a significant difference in the dynamics of Bcl- $\mathrm{X}_{\mathrm{L}}$ (antiapoptotic protein) and Bad (apoptotic protein) between HEC1 and HEC50B cells during $\mathrm{E}_{2}$-disturbed mitochondrial membrane potential. In conclusion, the susceptibility to $\mathrm{E}_{2}$ and the dynamics of Bcl-2 family proteins treated with $E_{2}$ have been changing as becoming the malignancy of endometrial cancer cells, interestingly.

\section{Materials and Methods}




\section{Source and Cell culture}

We used two cell lines: Grade II endometrial carcinoma HEC1 cells, and Grade III endometrial carcinoma HEC50B cells. These cells were obtained from the Japan Health Sciences Foundation (Tokyo, Japan). Cells were cultured in Dulbecco's Modified Eagle's Medium (DMEM) supplemented with 10\% heat-inactivated bovine serum and 20 $\mathrm{mmol} / \mathrm{L}$ of L-Glutamine without phenol red at $37^{\circ} \mathrm{C}$ in a $5 \% \mathrm{CO}_{2}$ incubator.

\section{Cell viability}

Cell viability for 5,000 cells per 96-well plate was evaluated by MTT (3-(4,5Dimethyl-2-thiazolyl)-2,5-diphenyl-2H-tetrazolium bromide) assay. Cells were cultured for $24 \mathrm{~h}$ and $48 \mathrm{~h}$ in serum-free DMEM in the presence or absence of $\mathrm{E}_{2}$. After $24 \mathrm{~h}$ or $48 \mathrm{~h}, 20 \mu \mathrm{L}$ of MTT solution $(5 \mathrm{mg} / \mathrm{mL})$ was added to each well, samples were incubated for $2 \mathrm{~h}$ at $37^{\circ} \mathrm{C}$. After $100 \mu \mathrm{L}$ of stop solution $(20 \%$ SDS, $50 \%$ dimethyl formamide) was added to each cell, samples were incubated for overnight at room temperature and were measured by absorbance at $570 \mathrm{~nm}$ with Microplate reader ( $\mathrm{SH}-$ 9000) (CORONA ELECTRIC, Ibaragi, Japan). Data are expressed as percentage of independent basal levels.

\section{Reverse transcription-polymerase chain reaction (RT-PCR)}

Cells were scraped and total RNAs were purified using TRIzol reagent (Thermo Fisher Scientific, Kanagawa, Japan). Subsequently, $5 \mu \mathrm{g}$ of total RNAs was used for cDNA synthesis. $\quad$ RT reaction was performed using Reverse transcriptase, M-MLV, RNase $\mathrm{H}^{+}$ (Wako, Osaka, Japan) according to manufacturer's instructions. Each cDNA (1 $\mu \mathrm{L})$ was amplified with rTaq polymerase (TOYOBO, Osaka, Japan) and loaded in a thermal cycler (Thermo Fisher Scientific, Kanagawa, Japan) with the following steps: first step, $94^{\circ} \mathrm{C}$ for $2 \mathrm{~min}$ followed by 30 cycles, $94^{\circ} \mathrm{C}$ for $1 \mathrm{~s}, 62^{\circ} \mathrm{C}$ for $15 \mathrm{~s}$ and $72^{\circ} \mathrm{C}$ for $30 \mathrm{~s}$. The reaction was carried out using primers (Table 1).

\section{Assay of mitochondrial membrane potentials}

We visualized mitochondrial membrane potentials using DePsipher ${ }^{\mathrm{TM}}$ kit (Trevigen, MD, USA). Cells were incubated in a presence and absence of $E_{2}$ for $6 \mathrm{~h}$. After washing with phosphate buffered saline (PBS), cells were incubated in a DePsipher ${ }^{\mathrm{TM}} \mathrm{kit}$ solution at $37^{\circ} \mathrm{C}$ for $30 \mathrm{~min}$. After washing with PBS, the fluorescent signals were 
observed with BZ-X810 (KEYENCE, Tokyo, Japan). The aggregate red form has absorption/emission of $585 / 590 \mathrm{~nm}$ and the green monomeric form has absorption/emission of 510/527 $\mathrm{nm}$.

\section{Mitochondria extraction}

Cells were treated with $\mathrm{E}_{2}$ or vehicle control for $6 \mathrm{~h}$ and collected cells. Cells were sonicated with $200 \mu \mathrm{L}$ of mitochondria fraction solution [250 mM sucrose, $0.5 \mathrm{mM}$ EGTA, $10 \mathrm{mM}$ Tris- $\mathrm{HCl}$ (pH7.4)]. After centrifugation at $1,000 \mathrm{~g}$ for $10 \mathrm{~min}$, supernatant ( $\sup$ ) was transferred into a new tube. After centrifugation at $8,000 \mathrm{~g}$ for 10 min, sup was transferred into a new tube and these samples were used as cytosol fraction. The pellet (ppt) was lysed with $50 \mu \mathrm{L}$ of TBST [150 mM NaCl, $0.1 \%(\mathrm{v} / \mathrm{v})$ Triton X-100 and $20 \mathrm{mM}$ Tris- $\mathrm{HCl}(\mathrm{pH} 7.4)]$ and vortexed vigorously. After centrifugation at 5,000 rpm for $5 \mathrm{~min}$, sup was used as mitochondria fraction. Subsequently, we carried out Western blotting.

\section{Western blotting}

The protein concentration of each sample was measured with a BCA protein assay kit (Takara Bio, Shiga, Japan). Lysates from mitochondria fraction $(5 \mu \mathrm{g})$ and cytosol fraction $(10 \mu \mathrm{g})$ were loaded onto $15 \%(\mathrm{v} / \mathrm{v})$ sodium dodecyl sulfate polyacrylamide gel electrophoresis (SDS-PAGE) and transferred to polyvinylidene difluoride (PVDF) membranes. PVDF membranes were blocked in TBST containing 1\% BSA and incubated with antibodies against Bcl-2, Bcl-X $\mathrm{L}, \mathrm{Bad}$, Bax, Cyt c (Abcam, Tokyo, Japan), and $\beta$-actin (Sigma-Aldrich, Tokyo, Japan) followed by Histofine Simple Stain MAXPO (Nichirei Bioscience, Tokyo, Japan). Immunoreactivity was detected with an ECL plus (GE healthcare, NJ, USA) and visualized using MultiImager II chemBox (Ikeda Trading Corporation, Tokyo, Japan). Signal density was measured with an Image $\mathbf{J}$ software.

\section{Enzymatic assay of caspase activity}

Caspase activation was measured using a caspase fluorometric substrates; Ac-Leu-GluHis-Asp-MCA for caspase-9 substrate peptide and Ac-Asp-Asn-Leu-Asp-MCA for caspase-3 substrate peptide (PEPTIDE institute, Osaka, Japan). Cells were incubated in a presence and absence of $E_{2}$ for $12 \mathrm{~h}$. Protein $(50 \mu \mathrm{g})$ was mixed with PBS and 
substrate peptide $(10 \mu \mathrm{M})$ followed by incubating $37^{\circ} \mathrm{C}$ for $2 \mathrm{~h}$. After that, the fluorescent signals were measured using a spectrofluorometer (RF-5300) (Shimadzu, Kyoto, Japan) with excitation at $380 \mathrm{~nm}$ and emission at $460 \mathrm{~nm}$.

\section{Statistical analysis}

Data from 4 to 7 independent experiments are expressed as mean \pm SEM. Statistical analysis was carried out using unpaired $t$-test. $P$ values below 0.05 were considered statistically significant.

\section{Results}

\section{$E_{2}$ decreases cell viability in $\mathrm{HEC1}$ and $\mathrm{HEC50B}$ cells}

We investigated the effect of $E_{2}$ on cell viability in endometrial cancer cells, such as HEC1 cells (Grade II) and HEC50B cells (Grade III). $E_{2}$ decreased cell viability in a concentration-dependent manner $(100 \mathrm{nM}-100 \mu \mathrm{M})$ at $24-\mathrm{h}$ and 48 -h treatment, with reaching 38.9\% $\pm 1.57(P<0.01)$ and $43.7 \% \pm 1.39(P<0.01)$, respectively. On the other hand, $\mathrm{E}_{2}$ attenuated cell viability at concentration above $50 \mu \mathrm{M}$ in HEC50B cells, with reaching 52.7\% $\pm 0.92(P<0.01)$ and 55.1\% $\pm 1.53(P<0.01)$ at $24-\mathrm{h}$ and 48 -h treatment, respectively. There was no critical difference between 24-h treatment and 48-h treatment in HEC1 and HEC50B cells. These results suggest that $\mathrm{E}_{2}$ significantly downregulated the cell viability of HEC1 and HEC50B cells, especially at concentrations above $50 \mu \mathrm{M}$.

\section{$E_{2}$-induced estrogen receptor mRNA expression in HEC1 and HEC50B cells}

Subsequently, we examined the expression of estrogen receptor (ER) and estrogenrelated receptor (ERR) using RT-PCR in HEC1 cells (Fig. 2a: upper panel) and HEC50B cells (Fig. 2a: lower panel). ERR $\alpha$ mRNA only was expressed in HEC1 and HEC50B cells, however, ER $\alpha, E R \beta, E R R \beta$ and ERR $\gamma$ mRNAs were not expressed. $\quad E_{2}(50 \mu \mathrm{M})$ did not change the expression of ER $\alpha, E R \beta, E R R \alpha, E R R \beta$ and ERR $\gamma$ mRNA in HEC1 cells (Figure 2b: upper panels) and HEC50B cells (Fig. 2b: lower panels). These results suggest that $\mathrm{E}_{2}$ reduces cell viability via the $\mathrm{ERR} \alpha$ pathway and that $\mathrm{E}_{2}$-induced cell death may not be related to de novo protein synthesis. 


\section{$\mathrm{E}_{2}$ disturbs mitochondrial membrane potentials in HEC1 and HEC50B cells}

We investigated whether $\mathrm{E}_{2}(50 \mu \mathrm{M})$-induced cell death is mediated by a disturbance in mitochondrial membrane potential in HEC1 and HEC50B cells. The mitochondrial membrane potentials were visualized using DePsipher ${ }^{\mathrm{TM}}$ kit. In both cells, the red fluorescent signals alone were found in control cells (Fig. 3a, 3b: upper panels). In contrast, $\mathrm{E}_{2}(50 \mu \mathrm{M})$-treated cells were observed the green fluorescent signals (Fig. 3a, 3b: lower panels). These data imply that 6-h treatment with $E_{2}(50 \mu \mathrm{M})$ disturbs mitochondrial membrane potentials in HEC1 and HEC50B cells. Thus, $\mathrm{E}_{2}(50 \mu \mathrm{M})-$ induced cell death was mitochondrial-dependent apoptosis in HEC1 and HEC50B cells.

\section{$E_{2}$ changes the dynamics of Bcl-2 family proteins on mitochondria in HEC1 and HEC50B cells}

To examine the mechanisms of disturbance of mitochondrial membrane potential induced by $\mathrm{E}_{2}(50 \mu \mathrm{M})$, we focused on the localization and expression of Bcl-2 family proteins at the mitochondrial outer membrane. In HEC1 cells, 6-h treatment with $\mathrm{E}_{2}$ (50 $\mu \mathrm{M})$ attenuated Bcl-2 and Bad expression level at mitochondria $(P<0.01$ and $P<0.01$ as compared with non-treatment cells, respectively, $t$-test) (Fig. 4b, 4c). $\mathrm{E}_{2}(50 \mu \mathrm{M})$ enhanced the expression of $\mathrm{Bcl}-\mathrm{X}_{\mathrm{L}}$ and $\mathrm{Bax}$ at mitochondria $(P<0.01$ and $P=0.04$ as compared with non-treatment cells, respectively, $t$-test) (Fig. 4a, 4d). In HEC50B cells, on the other hand, $\mathrm{E}_{2}(50 \mu \mathrm{M})$ decreased $\mathrm{Bcl}-\mathrm{X}_{\mathrm{L}}$ and $\mathrm{Bcl}-2$ expression at mitochondria ( $P=0.04$ and $P<0.01$ as compared with non-treatment cells, respectively, $t$-test) (Fig. 5a, 5b). $\mathrm{E}_{2}(50 \mu \mathrm{M})$ increased the expression of $\mathrm{Bad}$ and $\mathrm{Bax}$ at mitochondria $(P=0.05$ and $P=0.05$ as compared with non-treatment cells, respectively, $t$-test) (Fig. 5c, 5d). These results suggest that the localization and expression of Bcl-2 family proteins induced by $\mathrm{E}_{2}(50 \mu \mathrm{M})$ had different regulation between HEC1 and HEC50B cells, notably Bcl- $\mathrm{X}_{\mathrm{L}}$ and Bad. To obtain further evidence for the effect of $E_{2}(50 \mu \mathrm{M})$ on mitochondria, we examined the expression of mitochondrial Cyt c. In both cells, $E_{2}$ significantly accelerated the release of Cyt $\mathrm{c}$ from mitochondria in HEC1 and HEC50B cells $(P<0.01$ and $P=0.02$ as compared with non-treatment cells, respectively, $t$-test) (Fig. 4e, Fig. 5e). These results suggest that $6-\mathrm{h}$ treatment with $\mathrm{E}_{2}(50 \mu \mathrm{M})$ accelerates the disappearance of mitochondrial Cyt $\mathrm{c}$ in HEC1 and HEC50B cells. 


\section{$E_{2}$ enhances caspase-9 and caspase-3 activity through mitochondrial damage in HEC1 and HEC50B cells}

Finally, we investigated whether the disturbance of the mitochondrial membrane potentials led to activate caspase-9. In HEC1 cells, $E_{2}(50 \mu \mathrm{M})$ activated caspase-9 (Fig. 6a) and caspase-3 (Fig. 6b), reaching 117.0\% $\pm 4.5(P<0.01)$ and 112.0\% $\pm 2.1(P<0.01)$ at 12-h treatment, respectively. In HEC50B cells, $\mathrm{E}_{2}(50 \mu \mathrm{M})$ also accelerated caspase9 (Fig. 7a) and caspase-3 (Fig. 7b) activity, reaching $112.3 \% \pm 2.6(P=0.03)$ and $117.0 \%$ $\pm 2.7(P=0.03)$ at $12-\mathrm{h}$ treatment, respectively. These results suggest that $\mathrm{E}_{2}(50 \mu \mathrm{M})$ disturbs mitochondrial membrane potential followed by facilitating the activity of caspase-9/-3.

\section{Discussion}

In the present study, $\mathrm{E}_{2}(50 \mu \mathrm{M})$ induced apoptosis in HEC1 cells (Grade II) and HEC50B cells (Grade III). In a previous report, we reported that $\mathrm{E}_{2}(1 \mu \mathrm{M})$ promoted cell viability by increasing the expression of ATP-binding cassette G2 (ABCG2) in Ishikawa 3H-12 cells (Grade I) [22]. Moreover, the effect of the endocrine disruptor bisphenol A (BPA) on cell viability in grade of endometrial cancer cells only enhanced cell proliferation in Ishikawa 3-H-12 cells (Grade I) and HEC265 cells (Grade I). However, HEC151 cells (Grade II), HEC251 cells (Grade II), HEC108 cells (Grade III) and HEC50B cells (Grade III) were not affected by BPA treatment [23]. These results implied that the susceptibility to drugs such as $\mathrm{E}_{2}$ and BPA differed depending on the grade of endometrial cancer cells. As becoming high-grade endometrial cancer cells, major changes may have occurred at the epigenetic and proteomic levels in these cells. The results of the present study demonstrated that the dynamics of Bcl-2 family, such as $\mathrm{Bcl}-\mathrm{X}_{\mathrm{L}}, \mathrm{Bcl}-2, \mathrm{Bad}$, and $\mathrm{Bax}$, on the mitochondrial membrane after $\mathrm{E}_{2}$ stimulation is different between HEC1 and HEC50B cells. Anti-apoptotic proteins, Bcl-2 and Bcl- $\mathrm{X}_{\mathrm{L}}$, etc., and apoptotic proteins, Bad and Bax, etc., are called as Bcl-2 family. Bcl-2 family is divided into three groups according to the difference in function, (A) anti-apoptotic proteins (Bcl-2, Bcl-X $\mathrm{L}_{\mathrm{L}}, \mathrm{MCL}-1$, etc.) including Bcl-2 homology (BH) 1, BH2, BH3 and BH4, (B) pro-apoptotic BH3-only proteins (Bad, Bid, Bik and Bim, etc.), and (C) proapoptotic pore-formers (Bax and Bak, etc.) including $\mathrm{BH} 1, \mathrm{BH} 2$ and $\mathrm{BH} 3$ [24-27]. These BH3-only proteins induce structural changes by binding to Bax, furthermore, 
induce apoptosis with counteracting anti-apoptotic effect by binding to Bcl-2. The oligomerize of pro-apoptotic pore-forming proteins within the mitochondrial outer membrane induces the permeabilize mitochondrial membrane followed by releasing Cyt $\mathrm{c}$ and SMAC/DIABLO $[28,29] . \quad \mathrm{E}_{2}(50 \mu \mathrm{M})$ upregulated the expression of Bcl-X $\mathrm{X}_{\mathrm{L}}$ and Bax at the mitochondrial outer membrane, however, downregulated the expression of Bcl-2 and Bax at the mitochondrial outer membrane in HEC1 cells. On the other hand, $\mathrm{E}_{2}(50 \mu \mathrm{M})$ enhanced the expression of $\mathrm{Bcl}-\mathrm{X}_{\mathrm{L}}$ and $\mathrm{Bcl}-2$ at the mitochondrial outer membrane, however, reduced the expression of $\mathrm{Bad}$ and $\mathrm{Bax}$ at the mitochondrial outer membrane in HEC50B cells. Interestingly, $\mathrm{E}_{2}(50 \mu \mathrm{M})$ stimulation induced apoptosis in HEC1 and HEC50B cells, however the expression of Bcl- $\mathrm{X}_{\mathrm{L}}$ and $\mathrm{Bad}$ on mitochondria showed the opposite expression pattern between HEC1 and HEC50B cells (Fig. 4, 5, 8). In HEC50B cells, notably, the localization and expression of $\mathrm{Bcl}-\mathrm{X}_{\mathrm{L}}$ and $\mathrm{Bad}$ was a typical expression pattern during apoptosis. In contrast, the localization and expression of Bcl- $\mathrm{X}_{\mathrm{L}}$ and $\mathrm{Bad}$ were consistent with those of anti-apoptosis in HEC1 cells. We hypothesized that as endometrial cancer cells become high grade, the affinities and localization of Bcl-2 family proteins induced by $\mathrm{E}_{2}$ may be shifting from anti-apoptotic to apoptotic patterns. Generally, it is well-known that Bcl- $\mathrm{X}_{\mathrm{L}}$ plays an important role in apoptosis, and the increase of Bcl- $\mathrm{X}_{\mathrm{L}}$ expression at mitochondria indicates the inhibition of the disturbance of the mitochondrial membrane potential. According to a previously report, co-expression of $\mathrm{Bcl}-\mathrm{X}_{\mathrm{L}}$ and $\mathrm{p} 53$ is important for cell survival, thus, $\mathrm{Bcl}-\mathrm{X}_{\mathrm{L}}$ induced the survival of cancer cells by inhibiting the function of p53 [30, 31]. In RTPCR analysis, p53 mRNA was expressed in HEC1 cells but not HEC50B cells (Supplementary Fig. 1a, b). Moreover, the expression of p53 mRNA was not induced by $E_{2}(50 \mu \mathrm{M})$ (Supplementary Fig. 1a, b). The disruption of the mitochondrial membrane potential by $\mathrm{E}_{2}$ treatment is thought to occur independently of p53 in HEC1 and HEC50B cells. On the other hand, Bad is a member of BH3-only gamily and does not have transmembrane domain. The $\mathrm{BH} 3$ domain of activator $\mathrm{BH} 3$-only proteins such as Bad and Bid binds to the BH3 domain-binding groove in Bax followed by eliciting a series of conformation changes such as Bax homo-oligomerization and pore formation $[32,33]$. Therefore, these results suggest that the decrease of the expression of Bad on the mitochondrial outer membrane indicated resistance to $\mathrm{E}_{2}$-induced apoptosis in HEC1 cells. However, it remains unknown what kind of dimers of Bcl-2 family proteins are formed on the mitochondrial outer membrane during $\mathrm{E}_{2}$-induced apoptosis in HEC1 and 
HEC50B cells. We are currently carrying out examining the partners of Bcl-2 family proteins at the mitochondrial outer membrane using immunoprecipitation during $\mathrm{E}_{2}$ induced apoptosis in HEC1 and HEC50B cells.

Caspase is one of the apoptosis-induced factors and plays an important role in programmed cell death. Caspase-9/-3 pathway is downstream of the disturbance of the mitochondrial membrane potential. Cyt $\mathrm{c}$ and SMAC/DIABLO are released from mitochondria to cytosol through Bax pore during mitochondria-dependent apoptosis [34]. Cytosolic Cyt c binds apoptosis protease-activating factor 1 (APAF-1) and accelerates the formation of apoptosome. After that, apoptosome recruited and activated the initiator caspase procaspase-9. On the other hand, SMAC/DIABLO inhibits the inhibitor of apoptosis (IAP), a suppressor of caspase-9. In the present study, we examined on mitochondrial dynamics of Cyt $\mathrm{c}$ in HEC1 and HEC50B cells. Mitochondrial Cyt c was decreased as compared with non-treatment cells significantly. The disappearance of mitochondrial Cyt $\mathrm{c}$ by $\mathrm{E}_{2}$ treatment caused to disturb the mitochondrial membrane potential in HEC1 and HEC50B cells. The disturbance of the mitochondrial membrane potential induced to activate caspase- 9 followed by activating caspase-3 in HEC1 and HEC50B cells. We expected to observe the increase of cytosolic Cyt $\mathrm{c}$ treated with $\mathrm{E}_{2}$, however cytosolic Cyt $\mathrm{c}$ was not significantly increased in HEC1 and HEC50B cells. These results suggest that $\mathrm{E}_{2}$ may activate caspase via a cytosolic Cyt c-independent pathway in HEC1 and HEC50B cells. In future, it is necessary to investigate whether $\mathrm{E}_{2}$ induces apoptosis through a SMAC/DIABLO pathway in both cells.

In conclusion, we obtained a new evidence that there was the relationship with the localization and expression of Bcl-2 family proteins and the malignance of endometrial cancer cells. Especially, as the cells became high grade of endometrial cancer cells, the expression of Bcl- $\mathrm{X}_{\mathrm{L}}$ at mitochondrial was changed from increase to decrease, and the expression of Bax was changed from decrease to increase during $\mathrm{E}_{2}$-induced apoptosis. These results may exhibit a useful marker of the malignance of endometrial cancer cells.

\section{Acknowledgments}

We would like to thank Kanae Ikeda, Kana Suto, Mika Higuchi, Ayaka Miyazaki, Sakura Motoyama, Suzuka Yamaguchi, Yuki Yokota, Rie Yoshigai, Yuta Nakamura, 
Yuka Tsutsumi, Natsumi Kondo, Hitomi Furukawa, Miho Masuda, Erina Maruoka, Momoka Yamaguchi, Ayaka Ikenaga, Sumire Kawasaki, Ayase Sato, Kotone Shimoda, Suzuka Tanaka, Runa Toyota, Kojiro Nishioka, Kotone Fukuda, Yuka Matsumoto, Akari Omoto, Mana Sakita, Kazusa Tadakuma, Riko Nogata, Momoka Hatanaka, Haruna Yamaguchi, Mirai Yamaguchi and Miyu Yamada for their contributions and helpful discussions. This research did not receive any specific grants from funding agencies in the public, commercial, or not-for-profit sectors.

\section{Conflict of interests}

The authors declare no conflicts of interest in association with the present study.

\section{References}

1. Suarez AA, Felix AS, Cohn DE. (2017) Bokhman Redux: Endometrial cancer "types" in the 21 st century. Gynecol Oncol 144(2): 243-249.

2. Beverly Long, Jenna Lilyquist, Amy Weaver, Chunling Hu, Rohan Gnanaolivu, Kun Y Lee, Steven N Hart, Eric C Polley, Jamie N Bakkum-Gamez, Fergus J Couch, Sean C Dowdy. (2019) Cancer susceptibility gene mutations in type I and II endometrial cancer. Gynecol Oncol. 152(1):20-25.

3. Lei Deng, Russell R Broaddus, Adrienne McCampbell, Gregory L Shipley, David S Loose, George M Stancel, James H Pickar, Peter J A Davies. (2005) Identification of a novel estrogen-regulated gene, EIG121, induced by hormone replacement therapy and differentially expressed in type I and type II endometrial cancer. Clin Cancer Res. 11(23):8258-64.

4. Veronica Wendy Setiawan, Hannah P Yang, Malcolm C Pike, Susan E McCann, Herbert Yu, Yong-Bing Xiang, Alicja Wolk, Nicolas Wentzensen, Noel S Weiss, Penelope M Webb, Piet A van den Brandt, Koen van de Vijver, Pamela J Thompson, Australian National Endometrial Cancer Study Group; Brian L Strom, Amanda B Spurdle, Robert A Soslow, Xiao-ou Shu, Catherine Schairer, Carlotta 
Sacerdote, Thomas E Rohan, Kim Robien, Harvey A Risch, Fulvio Ricceri, Timothy R Rebbeck, Radhai Rastogi, Jennifer Prescott, Silvia Polidoro, Yikyung Park, Sara H Olson, Kirsten B Moysich, Anthony B Miller, Marjorie L McCullough, Rayna K Matsuno, Anthony M Magliocco, Galina Lurie, Lingeng Lu, Jolanta Lissowska, Xiaolin Liang, James V Lacey Jr, Laurence N Kolonel, Brian E Henderson, Susan E Hankinson, Niclas Håkansson, Marc T Goodman, Mia M Gaudet, Montserrat GarciaClosas, Christine M Friedenreich, Jo L Freudenheim, Jennifer Doherty, Immaculata De Vivo, Kerry S Courneya, Linda S Cook, Chu Chen, James R Cerhan, Hui Cai, Louise A Brinton, Leslie Bernstein, Kristin E Anderson, Hoda Anton-Culver, Leo J Schouten, Pamela L Horn-Ross. (2013) Type I and II endometrial cancers: have they different risk factors? J Clin Oncol. 31(20):2607-18.

5. Giuseppe Gullo, Andrea Etrusco, Gaspare Cucinella, Antonino Perino, Vito Chiantera, Antonio Simone Laganà, Rossella Tomaiuolo, Amerigo Vitagliano, Pierluigi Giampaolino, Marco Noventa, Alessandra Andrisani, Giovanni Buzzaccarini (2021) Fertility-Sparing Approach in Women Affected by Stage I and Low-Grade Endometrial Carcinoma: An Updated Overview. Int J Mol Sci. 31;22(21):11825.

6. Min Wu, Ya-Nan Yang, Yu-Hui Huang, Jing Cai, Xiao-Qi He, Ze-Hua Wang (2021) Adjuvant Chemotherapy versus Radiotherapy in High-risk, Early-stage Endometrioid Endometrial Carcinoma. Curr Med Sci. doi: 10.1007/s11596-021-2437-8.

7. Muzaffer Sanci, Kemal Güngördük, Varol Gülseren, Tuğba Karadeniz, Mustafa Kocaer, Ozgu Gungorduk, İsa A Özdemir. (2018) MELF Pattern for Predicting Lymph Node Involvement and Survival in Grade I-II Endometrioid-type Endometrial Cancer. Int J Gynecol Pathol. 37(1):17-21.

8. Soheila Sarmadi, Narges Izadi-Mood, Nazanin Mansourzadeh, Dorna Motevalli (2019) Expression in High-Grade Endometrial Carcinoma and Its Clinicopathological Correlation. Iran J Pathol 2019;14(4):322-328. 
9. Kemi M Doll, Jill Tseng, Sheri A Denslow, Amanda Nickles Fader, Paola A Gehrig. (2013) High-grade endometrial cancer: revisiting the impact of tumor size and location on outcomes. Gynecol Oncol. 132(1):44-9.

10. Emily A Goebel, August Vidal, Xavier Matias-Guiu C Blake Gilks. (2018) The evolution of endometrial carcinoma classification through application of immunohistochemistry and molecular diagnostics: past, present and future. Virchows Arch. 472(6):885-896.

11. J. Marie Hardwick, Lucian Soane. (2013) Multiple Functions of BCL-2 Family Proteins. Cold Spring Harb Perspect Biol. doi: 10.1101/cshperspect.a008722

12. Shamas-Din A, Brahmbhatt H, Leber B, Andrews DW. (2011) BH3-only proteins: orchestrators of apoptosis. Biochim Biophys Acta 2011; 1813: 508-520.

13. Antonio Raffone, Antonio Travaglino, Massimo Mascolo, Consolata Carotenuto, Maurizio Guida, Antonio Mollo, Luigi Insabato, Fulvio Zullo. (2020) Histopathological characterization of ProMisE molecular groups of endometrial cancer. Gynecol Oncol. 157(1):252-259.

14. Chen Zheng, Ting Liu, Huihui Liu, Jing Wang. (2020) Role of BCL-2 Family Proteins in Apoptosis and its Regulation by Nutrients. Curr Protein Pept Sci. 2020;21(8):799-806.

15. Mathilde Rikje, Willemijn de Jong, Myra Langendonk, Bart Reitsma Marcel Nijland, Anke van den Berg, Emanuele Ammatuna, Lydia Visser, Tom van Meerten. (2019) Heterogeneous Pattern of Dependence on Anti-Apoptotic BCL-2 Family Proteins upon CHOP Treatment in Diffuse Large B-Cell Lymphoma. Int J Mol Sci. 30;20(23):6036.

16. Victor Vasquez-Montes, Mykola V Rodnin, Alexander Kyrychenko, Alexey S Ladokhin. (2021) Lipids modulate the BH3-independent membrane targeting and 
activation of BAX and Bcl-xL. Proc Natl Acad Sci U S A. 118(37):e2025834118. doi: 10.1073/pnas.2025834118.

17. Liora Lindenboim, Dan Grozki, Ayelet $\mathrm{R}$ Amsalem-Zafran, Aida PeñaBlanco, Gregg G Gundersen, Christoph Borner, Didier Hodzic, Ana J GarciaSáez, Howard J Worman Reuven Stein (2020) Apoptotic stress induces Bax-dependent, caspase-independent redistribution of LINC complex nesprins. Cell Death Discov. 6:90. doi: 10.1038/s41420-020-00327-6. eCollection 2020.

18. Nguyen Nhat Huynh Mai, Yuya Yamaguchi, Narantsog Choijookhuu, Jin Matsumoto, Atsushi Nanashima, Hideaki Takagi, Katsuaki Sato, Le Quoc Tuan, Yoshitaka Hishikawa. (2021) Photodynamic Therapy Using a Novel Phosphorus Tetraphenylporphyrin Induces an Anticancer Effect via Bax/Bcl-xL-related Mitochondrial Apoptosis in Biliary Cancer Cells. Acta Histochem Cytochem. 26;53(4):61-72.

19. Joshua A Grosser, Margaret E Maes, Robert W Nickells. (2021) Characteristics of intracellular propagation of mitochondrial BAX recruitment during apoptosis. Apoptosis. 26(1-2):132-145.

20. Franziska Mueller, Alexandra Friese, Claudio Pathe, Richard Cardoso da Silva, Kenny Bravo Rodriguez, Andrea Musacchio, Tanja Bange. (2021) Overlap of NatA and IAP substrates implicates N-terminal acetylation in protein stabilization. (2021) 7(3):eabc8590. doi: 10.1126/sciadv.abc8590.

21. Magali Espinosa, Floria Lizárraga, Karla Vázquez-Santillán, Alfredo HidalgoMiranda, Patricia Piña-Sánchez, Javier Torres, Román A García-Ramírez, Vilma Maldonado, Jorge Melendez-Zajgla, Gisela Ceballos-Cancino. (2021) Coexpression of Smac/DIABLO and Estrogen Receptor in breast cancer. Cancer Biomark. 30(4):429-446.

22. Takahiro Yaguchi, Takafumi Onishi. (2018) Estrogen induces cell proliferation by promoting ABCG2-mediated efflux in endometrial cancer cell. Biochemistry and Biophysics Reports. 16:74-78. 
23. Takahiro Yaguchi. (2019) The endocrine disruptor bisphenol A promotes nuclear ERR $\gamma$ translocation, facilitating cell proliferation of Grade I endometrial cancer cells via EGF-dependent and EGF-independent pathways. Molecular and Cellular Biochemistry 452(1-2):41-50.

24. Karl L Banta, Xinyue Wang, Phani Das, Astar Winoto. (2018) B cell lymphoma 2 (Bcl-2) residues essential for Bcl-2's apoptosis-inducing interaction with Nur77/Nor-1 orphan steroid receptors. J Biol Chem. 293(13):4724-4734.

25. E Lomonosova, G Chinnadurai. (2008) BH3-only proteins in apoptosis and beyond: an overview. Oncogene. Suppl 1(Suppl 1):S2-19 doi: 10.1038/onc.2009.39.

26. Shamas-Din A, Brahmbhatt H, Leber B, Andrews DW. (2010) BH3only proteins: Orchestrators of apoptosis. Biochim Biophys Acta. 13(4):508-20.

27. L P Billen, A Shamas-Din, D W Andrews. (2008) Bid: a Bax-like BH3 protein. Oncogene. Suppl 1: S93-104. doi: 10.1038/onc.2009.47.

28. Naamwin R Meda, Tatjana Stevanovic, Patrice E Poubelle. (2019) Anhydroglucitol-core gallotannins from red maple buds modulate viability of human blood neutrophils. Toxicol In Vitro. 60:76-86.

29. Jieying Liu, So Youn Kim, Sun Shin, Seung-Hyun Jung, Seon-Hee Yim, Ji Youl Lee, Sug-Hyung Lee, Yeun-Jun Chung. (2018) Overexpression of TFF3 is involved in prostate carcinogenesis via blocking mitochondria-mediated apoptosis. Exp Mol Med. $50(8): 1-11$.

30. Hedyeh Ziai, Abdulrahman Alenazi, Matthew Hearn, Daniel A O'Connell, Lakshmi Puttagunta, Brittany Barber, Jeffrey R Harris, Hadi Seikaly, Vincent L Biron. (2019) The association of Bcl-xL and p53 expression with survival outcomes in oropharyngeal cancer. Cancer Biomark. 24(2):141-151. 
31. Xiaoyin $\mathrm{Xu}$, Hiroaki Iwasa, Shakhawoat Hossain, Aradhan Sarkar, Junichi Maruyama, Kyoko Arimoto-Matsuzaki, Yutaka Hata. (2017) BCL-XL binds and antagonizes RASSF6 tumor suppressor to suppress p53 expression. Genes Cells. 22(12):993-1003.

32. Liu Q, Moldoveanu T, Sprules T, Matta. (2013) Bax crystal structures reveal how BH3 domains activate Bax and nucleate its oligomerization to induce apoptosis. Cell. 152: 519-531.

33. Tudor Moldoveanu, Christy R Grace, Fabien Llambi, Amanda Nourse, Patrick Fitzgerald, Kalle Gehring, Richard W Kriwacki, Douglas R Green. (2013) BID-induced structural changes in BAK promote apoptosis. Nat Struct Mol Biol. 20: 589-597.

34. Hyun-Eui Kim, Fenghe Du, Min Fang, Xiaodong Wang. (2005) Formation of apoptosome is initiated by cytochrome c-induced dATP hydrolysis and subsequent nucleotide exchange on Apaf-1. Proc Natl Acad Sci U S A . 102(49):17545-50.

\section{Figure legends}

Fig. 1

$\mathrm{E}_{2}$ attenuates cell viability in HEC1 cells and HE50B cells. (a) HEC1 cells and (b) HEC50B cells were treated with $\mathrm{E}_{2}$ at concentration as indicated for $24 \mathrm{~h}$ and $48 \mathrm{~h}$. Cell viability for 5,000 cells per well (96 well) was measured using an MTT assay. In the graphs, each point represents the mean \pm SEM ratio of basal level ( $n=5-7$ independent experiments). $\quad * * P<0.01 ; * P<0.05, \dagger \dagger P<0.01 ; \dagger P<0.01, P$ values, unpaired $t$-test.

Fig. 2

RT-PCR analysis is performed for ER $\alpha, E R \beta, E R R \alpha, E R R \beta, E R R \gamma$ and GAPDH mRNA expressed in HEC1 cells (a: upper panel) and HEC50B cells (a: lower panel). HEC1 cells (b: upper panels) and HEC50B cells (b: lower panels) were treated with $\mathrm{E}_{2}$ $(50 \mu \mathrm{M})$ for $0,0.5,1,3$ and $6 \mathrm{~h}$ and RNA was extracted followed by RT-PCR. Note that a similar result was obtained with 3 independent experiments. 
Fig. 3

$\mathrm{E}_{2}(50 \mu \mathrm{M})$ disturbs mitochondrial membrane potentials in HEC1 cells sand HEC50B cells. HEC1 cells (a) and HEC50B cells (b) were treated with $\mathrm{E}_{2}(50 \mu \mathrm{M})$ for $12 \mathrm{~h}$ in serum free culture medium, and mitochondrial membrane potentials were observed with BZ-X810. The aggregate red form (a: left 2 panels, b: left 2 panels) was detected at an absorption/emission of 585/590 $\mathrm{nm}$ and the green monomeric form (a: right 2 panels, b: right 2 panels) was detected at an absorption/emission of 510/527 nm. Scale bars, 50 $\mu \mathrm{m}$. Note that a similar result was obtained with 4-5 independent experiments.

Fig. 4

$\mathrm{E}_{2}(50 \mu \mathrm{M})$ changes the expression and localization of Bcl-2 family and Cyt $\mathrm{c}$ in HEC1 cells. After 6-h treatment with $\mathrm{E}_{2}(50 \mu \mathrm{M})$, Western blotting for Bcl-X $\mathrm{L}_{\mathrm{L}}(\mathrm{a}), \mathrm{Bcl}-2$ (b), $\operatorname{Bad}(\mathrm{c}), \operatorname{Bax}(\mathrm{d})$, Cyt c (e) and $\beta$-actin (f) was performed in the mitochondrial and cytoplasmic fractions. In the graph, each column represents the mean $\pm \mathrm{SEM}$ ratio against basal normalized immunoreactive intensities for mitochondrial and cytoplasmic fractions untreated with $\mathrm{E}_{2}(50 \mu \mathrm{M})(\mathrm{n}=4-6$ independent experiments). $\quad * * P<0.01$; $* P<0.05, P$ values, unpaired $t$-test.

Fig. 5

$\mathrm{E}_{2}(50 \mu \mathrm{M})$ changes the expression and localization of Bcl-2 family and Cyt $\mathrm{c}$ in HEC50B cells. After 6-h treatment with $\mathrm{E}_{2}(50 \mu \mathrm{M})$, Western blotting for Bcl-X $\mathrm{X}$ (a), Bcl-2 (b), Bad (c), Bax (d), Cyt c (e) and $\beta$-actin (f) was performed in the mitochondrial and cytoplasmic fractions. In the graph, each column represents the mean $\pm \mathrm{SEM}$ ratio against basal normalized immunoreactive intensities for mitochondrial and cytoplasmic fractions untreated with $\mathrm{E}_{2}(50 \mu \mathrm{M})(\mathrm{n}=4-6$ independent experiments). $\quad * * P<0.01$; $* P<0.05, P$ values, unpaired $t$-test.

Fig. 6

$\mathrm{E}_{2}(50 \mu \mathrm{M})$ activates caspase-9 and caspase-3 in HEC1 cells. After 12-h treatment with $\mathrm{E}_{2}(50 \mu \mathrm{M})$, activities of caspase-9 (a) and -3 (b) were measured with spectrofluorometer (RF-5300). Note that a similar result was obtained with 5 independent experiments. $* * P<0.01, P$ values, unpaired $t$-test. 
Fig. 7

$\mathrm{E}_{2}(50 \mu \mathrm{M})$ activates caspase-9 and caspase-3 in HEC50B cells. After 12-h treatment with $\mathrm{E}_{2}(50 \mu \mathrm{M})$, activities of caspase-9 (a) and -3 (b) were measured with spectrofluorometer (RF-5300). Note that a similar result was obtained with 4-5 independent experiments. ${ }^{*} P<0.01 ;{ }^{*} P<0.05, P$ values, unpaired $t$-test.

Fig. 8

Schematic diagram for $\mathrm{E}_{2}$ signaling pathways.

Table 1

Primers used for RT-PCR.

Supplementary Fig. 1

RT-PCR analysis is performed for p53 mRNA expressed in HEC1 cells (a: upper panel) and HEC50B cells (b: lower panel). Cells were treated with $\mathrm{E}_{2}(50 \mu \mathrm{M})$ for 0 , $0.5,1,3$ and $6 \mathrm{~h}$ and RNA was extracted followed by RT-PCR. Note that a similar result was obtained with 3 independent experiments.

Supplementary Table 1

Primers used for RT-PCR. 


\section{Figures}

\section{Figure 1}

$\mathrm{E}_{2}$ attenuates cell viability in HEC1 cells and HE50B cells. (a) HEC1 cells and (b) HEC50B cells were treated with $E_{2}$ at concentration as indicated for $24 \mathrm{~h}$ and $48 \mathrm{~h}$. Cell viability for 5,000 cells per well (96 well) was measured using an MTT assay. In the graphs, each point represents the mean \pm SEM ratio of basal level ( $\mathrm{n}=5-7$ independent experiments). ${ }^{\star \star} P<0.01 ;{ }^{*} P<0.05, \mathrm{\dagger}+P<0.01 ;+P<0.01, \mathrm{P}$ values, unpaired $t$ test.

\section{Figure 2}

RT-PCR analysis is performed for ERa, ERß, ERRa, ERR 3 , ERRY and GAPDH mRNA expressed in HEC1 cells (a: upper panel) and HEC50B cells (a: lower panel). HEC1 cells (b: upper panels) and HEC50B cells (b: lower panels) were treated with E2 $(50 \mu \mathrm{M})$ for $0,0.5,1,3$ and $6 \mathrm{~h}$ and RNA was extracted followed by RTPCR. Note that a similar result was obtained with 3 independent experiments.

\section{Figure 3}

$\mathrm{E}_{2}(50 \mu \mathrm{M})$ disturbs mitochondrial membrane potentials in HEC1 cells sand HEC50B cells. HEC1 cells (a) and HEC50B cells $(b)$ were treated with $E_{2}(50 \mu \mathrm{M})$ for $12 \mathrm{~h}$ in serum free culture medium, and mitochondrial membrane potentials were observed with BZ-X810. The aggregate red form (a: left 2 panels, b: left 2 panels) was detected at an absorption/emission of 585/590 nm and the green monomeric form (a: right 2 panels, b: right 2 panels) was detected at an absorption/emission of 510/527 $\mathrm{nm}$. Scale bars, $50 \mu \mathrm{m}$. Note that a similar result was obtained with 4-5 independent experiments

\section{Figure 4}

$E_{2}(50 \mu \mathrm{M})$ changes the expression and localization of Bcl-2 family and Cyt $\mathrm{c}$ in HEC1 cells. After 6-h treatment with E2 $(50 \mu \mathrm{M})$, Western blotting for Bcl-X $\mathrm{X}_{\mathrm{L}}(\mathrm{a}), \mathrm{Bcl}-2$ (b), Bad (c), Bax (d), Cyt c (e) and $\beta$-actin (f) was performed in the mitochondrial and cytoplasmic fractions. In the graph, each column represents the mean \pm SEM ratio against basal normalized immunoreactive intensities for mitochondrial and cytoplasmic fractions untreated with E2 $(50 \mu \mathrm{M})\left(\mathrm{n}=4-6\right.$ independent experiments). ${ }^{\star \star} P<0.01 ;{ }^{*} P<0.05, \mathrm{P}$ values, unpaired $t$-test. 


\section{Figure 5}

$E_{2}(50 \mu \mathrm{M})$ changes the expression and localization of Bcl-2 family and Cyt $\mathrm{c}$ in HEC50B cells. After 6-h treatment with E2 $(50 \mu \mathrm{M})$, Western blotting for Bcl-XL (a), Bcl-2 (b), Bad (c), Bax (d), Cyt c (e) and $\beta$-actin (f) was performed in the mitochondrial and cytoplasmic fractions. In the graph, each column represents the mean \pm SEM ratio against basal normalized immunoreactive intensities for mitochondrial and cytoplasmic fractions untreated with E2 $(50 \mu \mathrm{M})\left(\mathrm{n}=4-6\right.$ independent experiments). ${ }^{\star \star} P<0.01 ;{ }^{*} P<0.05, P$ values, unpaired $t$-test.

\section{Figure 6}

$\mathrm{E}_{2}(50 \mu \mathrm{M})$ activates caspase-9 and caspase-3 in HEC1 cells. After 12-h treatment with E2 $(50 \mu \mathrm{M})$, activities of caspase-9 (a) and -3 (b) were measured with spectrofluorometer (RF-5300). Note that a similar result was obtained with 5 independent experiments. ${ }^{\star \star} P<0.01, P$ values, unpaired $t$-test.

\section{Figure 7}

$E_{2}(50 \mu M)$ activates caspase-9 and caspase-3 in HEC50B cells. After 12-h treatment with $E_{2}(50 \mu M)$, activities of caspase-9 (a) and -3 (b) were measured with spectrofluorometer (RF-5300). Note that a similar result was obtained with 4-5 independent experiments. ${ }^{*} P<0.01 ; * P<0.05, P$ values, unpaired $t$ test.

\section{Figure 8}

Schematic diagram for $\mathrm{E}_{2}$ signaling pathways.

\section{Supplementary Files}

This is a list of supplementary files associated with this preprint. Click to download.

- Table1Yaguchi.pdf

- SupplementalTable1Yaguchi.pdf

- supplyfig1Yaguchi.tif 